University of Nebraska - Lincoln

DigitalCommons@University of Nebraska - Lincoln

USDA National Wildlife Research Center - Staff Publications
U.S. Department of Agriculture: Animal and Plant Health Inspection Service

2013

\title{
Detecting an elusive invasive species: a diagnostic PCR to detect Burmese python in Florida waters and an assessment of persistence of environmental DNA
}

\author{
Antoinette J. Piaggio \\ USDA/APHIS/WS National Wildlife Research Center, Toni.J.Piaggio@aphis.usda.gov \\ Richard M. Engeman \\ USDA-APHIS-Wildlife Services, s_r100@yahoo.com \\ Matthew W. Hopken \\ USDA/APHIS/WS National Wildlife Research Center \\ John S. Humphrey \\ USDA/APHIS/WS National Wildlife Research Center, John.S.Humphrey@aphis.usda.gov \\ Kandy L. Keacher \\ United States Department of Agriculture, kandy.I.keacher@aphis.usda.gov
}

See next page for additional authors

Follow this and additional works at: https://digitalcommons.unl.edu/icwdm_usdanwrc

Piaggio, Antoinette J.; Engeman, Richard M.; Hopken, Matthew W.; Humphrey, John S.; Keacher, Kandy L.; Bruce, William E.; and Avery, Michael L., "Detecting an elusive invasive species: a diagnostic PCR to detect Burmese python in Florida waters and an assessment of persistence of environmental DNA" (2013). USDA National Wildlife Research Center - Staff Publications. 1241.

https://digitalcommons.unl.edu/icwdm_usdanwrc/1241

This Article is brought to you for free and open access by the U.S. Department of Agriculture: Animal and Plant Health Inspection Service at DigitalCommons@University of Nebraska - Lincoln. It has been accepted for inclusion in USDA National Wildlife Research Center - Staff Publications by an authorized administrator of DigitalCommons@University of Nebraska - Lincoln. 


\section{Authors}

Antoinette J. Piaggio, Richard M. Engeman, Matthew W. Hopken, John S. Humphrey, Kandy L. Keacher, William E. Bruce, and Michael L. Avery 


\title{
Detecting an elusive invasive species: a diagnostic PCR to detect Burmese python in Florida waters and an assessment of persistence of environmental DNA
}

\author{
ANTOINETTE J. PIAGGIO, * RICHARD M. ENGEMAN,* MATTHEW W. HOPKEN, * \\ JOHN S. HUMPHREY,+ KANDY L. KEACHER,† WILLIAM E. BRUCE† and MICHAEL L. AVERY† \\ *USDA, Wildlife Services, National Wildlife Research Center, Wildlife Genetics Lab, 4101 LaPorte Avenue, Fort Collins, CO \\ 80521, USA, +USDA, Wildlife Services, National Wildlife Research Center, Florida Field Station, 2820 E. University Ave., \\ Gainesville, FL 32641, USA
}

\begin{abstract}
Recent studies have demonstrated that detection of environmental DNA (eDNA) from aquatic vertebrates in water bodies is possible. The Burmese python, Python bivittatus, is a semi-aquatic, invasive species in Florida where its elusive nature and cryptic coloration make its detection difficult. Our goal was to develop a diagnostic PCR to detect $P$. bivittatus from water-borne eDNA, which could assist managers in monitoring this invasive species. First, we used captive $P$. bivittatus to determine whether reptilian DNA could be isolated and amplified from water samples. We also evaluated the efficacy of two DNA isolation methods and two DNA extraction kits commonly used in eDNA preparation. A fragment of the mitochondrial cytochrome $b$ gene from $P$. bivittatus was detected in all water samples isolated with the sodium acetate precipitate and the QIAamp DNA Micro Kit. Next, we designed $P$. bivittatus-specific primers and assessed the degradation rate of eDNA in water. Our primers did not amplify DNA from closely related species, and we found that $P$. bivittatus DNA was consistently detectable up to 96 h. Finally, we sampled water from six field sites in south Florida. Samples from five sites, where P. bivittatus has been observed, tested positive for eDNA. The final site was negative and had no prior documented evidence of $P$. bivittatus. This study shows $P$. bivittatus eDNA can be isolated from water samples; thus, this method is a new and promising technique for the management of invasive reptiles.
\end{abstract}

Keywords: Burmese python, DNA persistence, environmental DNA, PCR, Python bivittatus, reptile

Received 19 February 2013; revision received 19 September 2013; accepted 20 September 2013

\section{Introduction}

Molecular methods involving water-borne environmental DNA (eDNA) have proved useful for detecting various vertebrates, including invasive and endangered species (Ficetola et al. 2008; Goldberg et al. 2011; Jerde et al. 2011; Foote et al. 2012; Thomsen et al. 2012a). However, to our knowledge, eDNA methods have not been applied to reptile species. The Burmese python (Python bivittatus) is a large, invasive reptile (adult size may exceed $5 \mathrm{~m}$ ) in Florida. The species has been breeding in the wild in southern Florida for over a quarter century (Meshaka et al. 2000), with its invasion pathway tied to the pet trade, either through (illegal) pet releases or possibly through accidental releases from captive breeding and

Correspondence: Antoinette J. Piaggio, Fax: 970266 6063; E-mail: toni.j.piaggio@aphis.usda.gov holding facilities during Hurricane Andrew in 1992 (Snow et al. 2007b). Python bivittatus has become well established in areas, including Everglades National Park, and their consumption of a diverse range of vertebrate prey species, including native and/or endangered species (Greene et al. 2007; Smith et al. 2007; Snow et al. 2007a; Dorcas et al. 2012), has generated considerable concern. Monitoring this species is difficult due to their cryptic nature and occupation of aquatic habitats where surveys are costly and physically difficult. Therefore, a method for detecting the presence of $P$. bivittatus that eliminates the need for direct observations or handling would be a major benefit to the management of this invasive species. Further, a method to detect $P$. bivittatus eDNA could also be easily adapted for conservation efforts of rare aquatic or semi-aquatic reptile species such as endangered water snakes (Nerodia sp.) or detection of other invasive reptile species known to occur in Florida (Engeman et al. 2011). 
Free-ranging P. bivittatus are currently restricted to south Florida. Attempts to extrapolate the potential North American range for P. bivittatus have produced widely divergent and controversial predictions (Pyron et al. 2008; Rodda et al. 2009; Engeman et al. 2011; Jacobson et al. 2012). Such uncertainty of potential range occupancy underscores the need for developing means to assess whether an area has been colonized by the species. Further, a method that detects the presence of this invasive species in the environment would also be of great value in assessing success of eradications. Thus, the economic and management policy benefits for addressing the P. bivittatus problem are substantial (Smith et al. 2007). Python bivittatus' affinity for water provides an avenue for developing a method for detecting its presence using an eDNA approach.

Our concept was to initially use captive P. bivittatus in contained water sources and sample water for eDNA under controlled conditions. Failure to detect $P$. bivittatus DNA from these water sources would suggest that it would be improbable to obtain $P$. bivittatus DNA from any wild water source. However, the presence of $P$. bivittatus in such samples would suggest viability of developing a method that could assist management efforts in a field setting. To optimize isolation and purification of reptile DNA from water samples (eDNA), we tested multiple combinations of methods. We evaluated two methods for isolating DNA from water that have been used in other studies (Ficetola et al. 2008; Jerde et al. 2011); these were used in combination with two brands of DNA extraction kits commonly used to purify low quantity/quality DNA (Mo Bio PowerWater ${ }^{\circledR}$ Kit and QIAamp DNA Micro Kits). Once we found an optimal method for isolating and purifying P. bivittatus DNA from water, we then tested the persistence of that DNA. Such information could provide estimation of elapsed time since P. bivittatus DNA had been deposited in the water. Finally, we developed species-specific primers, tested their utility in captivity and assessed this method in a field setting by sampling and testing water from sites in southern Florida where P. bivittatus has and has not been observed.

\section{Materials and methods}

\section{Pen test I: isolation of Python bivittatus DNA from water}

We placed 5 captive P. bivittatus each (body mass mean $=8.49 \mathrm{~kg}, \mathrm{SD}=3.39$, range $4.40-13.45 \mathrm{~kg}$ ) in separate plastic trashcans filled with $90 \mathrm{~L}$ of well water for $2 \mathrm{~h}$. These snakes were trapped in south Florida and had been in captivity at the National Wildlife Research Center's (NWRC) Gainesville, Florida field station for
24-48 months. Water samples (5 L) were collected in autoclaved Nalgene bottles and shipped overnight on ice to the laboratory at NWRC headquarters in Fort Collins, Colorado. All laboratory work was conducted at a facility where DNA extractions, PCR and post-PCR procedures are conducted in separate rooms. Within $24 \mathrm{~h}$ of collection, we took two 15-mL aliquots and two 2-L aliquots of water. These provided four aliquots from each snake for testing the four combinations of two DNA isolation methods (sodium acetate precipitation and vacuum filtration) and the two DNA extraction kits (QIAGEN's QIAamp DNA Micro Kit and Mo Bio Laboratories' PowerWater ${ }^{\circledR}$ DNA Isolation Kit).

For isolation by sodium acetate precipitation, we added $1.5 \mathrm{~mL}$ of $3 \mathrm{~m}$ sodium acetate and $33 \mathrm{~mL}$ absolute ethanol to the $15-\mathrm{mL}$ aliquots of water (Valiere \& Taberlet 2000). We centrifuged this solution $(3220 \mathrm{~g}$, $45 \mathrm{~min}$, $6{ }^{\circ} \mathrm{C}$ ) and discarded the supernatant. We then added $10 \mathrm{~mL}$ of $70 \%$ ethanol to the pellet, briefly vortexed and then centrifuged $(3220 \mathrm{~g}, 10 \mathrm{~min})$. The ethanol was poured off, and the tubes were inverted on paper towels to dry. DNA was extracted from one pellet from each snake/water sample using the PowerWater ${ }^{\circledR}$ DNA Isolation Kit (Mo Bio Laboratories) by first adding $1 \mathrm{~mL}$ of PW1 to the pellet in 50-mL tubes and then transferring the solution to 2-mL tubes and following manufacturer's protocol from step 10. Extraction from the second pellet from each snake/water sample was accomplished using a QIAamp DNA Micro Kit (QIAGEN) following the Forensic Case Work Samples protocol (QIAamp DNA Micro Handbook August, 2003) with a final elution of $50 \mu \mathrm{L}$.

Each of the 2-L aliquots was vacuum-filtered onto Whatman $0.75-\mu \mathrm{m}$-pore-size glass fibre filter (Grade GF/F). This resulted in DNA isolation onto two filter papers per snake. We then used the PowerWater ${ }^{\circledR}$ DNA Isolation Kit following the manufacturer's protocol for one filter paper and the QIAamp DNA Micro Kit as described above. An extraction blank containing only kit reagents was included in all extraction sets to monitor contamination.

To test for P. bivittatus in the water samples, we amplified a portion of the mitochondrial DNA cytochrome $b$ (cyt $b$ ) gene using primers previously applied to P. bivittatus low quality/quantity DNA samples (Wong et al. 2004). Two $\mu \mathrm{L}$ of DNA template was amplified in a $25-\mu \mathrm{L}$ reaction containing $1.5 \mathrm{~mm} \mathrm{MgCl} 2,2.5 \mu \mathrm{L}$ 10× Amplitaq buffer (Life Technologies), 2 U Amplitaq (Life Technologies), $0.25 \mathrm{~mm}$ each dNTP, $1 \mu \mathrm{m}$ of each primer by the following PCR program: $15 \mathrm{~min}$ at $95^{\circ} \mathrm{C}$; 37 cycles of $1 \mathrm{~min}$ at $94{ }^{\circ} \mathrm{C}, 1.5 \mathrm{~min}$ at $50^{\circ} \mathrm{C}, 1 \mathrm{~min}$ at $72{ }^{\circ} \mathrm{C}$; with final extensions at $49{ }^{\circ} \mathrm{C}$ for $1 \mathrm{~min}$ and $72{ }^{\circ} \mathrm{C}$ for 4 min (Collins et al. 2008; B. Freeman, personal communication). Each PCR included a negative control and 
extraction blanks to monitor contamination in both the extraction and PCR reagents. Additionally, each PCR set included DNA extracted from P. bivittatus tissue as a positive control to verify the reaction was successful. Gel electrophoresis was conducted with $5 \mu \mathrm{L}$ of product mixed with $1.5 \mu \mathrm{L}$ of loading dye and with $100 \mathrm{bp}$ ladder (Affymetrix) in multiple wells of each gel. Sequencing of PCR amplified products was accomplished with ABI BigDye chemistry (Life Technologies). Cycle sequencing clean-up was accomplished with PrepEase (USB) protocols, and resulting sequences were visualized on an ABI3130xl genetic analyzer (Life Technologies).

Sequences were evaluated and edited using Sequencher (ver. 5.1; Gene Codes Corp.). To determine identification of sequences, we performed a BLAST search using the National Center for Biotechnology Information website (http://www.ncbi.nlm.nih.gov; Benson et al. 2012). Analytical comparisons among the detection rates for the four isolation by extraction combinations were conducted using Cochran's $Q$ statistic to account for the repeated measures design for binary data (i.e. each snake's water sample had two isolation methods, and each was extracted by two kits; total four measures for each snake/water sample).

\section{Assay design: species-specific primer design and protocol optimization}

The primers we used in the initial pen test were general cyt $b$ primers and known to amplify many snake species; hence, they lack specificity in detecting P. bivittatus DNA and would probably amplify multiple products if used for field tests. Therefore, we designed primers to amplify a fragment specifically from $P$. bivittatus of the cyt $b$ gene that was $<150$ base pairs (bp) in length (PybiCB3F $5^{\prime}$-ACCATACAAGTATTAACCGG-3'; PybiCB3R 5'- GTATGGAACATCGCGGG-3'). PCR of small fragments is more sensitive and efficient when targeting degraded DNA as expected to occur in eDNA samples (Deagle et al. 2006). Primer design was accomplished manually with alignments in Sequencher (ver. 5.1; Gene Codes Corp.) using sequences from Python bivittatus, P. sebae, P. molurus, $P$. reticulatus and $P$. regius (GenBank accession nos FJ717484, U69863, GQ225654, U69861 and U69857, respectively). Primer sequences were BLASTED on the National Center for Biotechnology Information website to assess specificity. PybiCB3F was labelled with fluorescent dye 6-FAM for visualization of fragments on an ABI3130xl genetic analyzer (Life Technologies). To test these primers, we used water samples from pen test I extracted with the optimal method, a positive control (DNA from P. bivittatus tissue), and monitored contamination with multiple PCR negative controls and extraction blanks. To assess specificity of our primers in
PCR, we also included tissue samples from three $P$. sebae obtained from the Florida Museum of Natural History (Catalogue numbers: 157206, 157300 and 155500) and three $P$. regius obtained from local reptile breeders in Florida. These species were chosen because they are both invasive pythons found in southern Florida and P. sebae is a sister taxon to P. bivittatus (Rawlings et al. 2008). Each PCR was a $25-\mu \mathrm{L}$ reaction containing $1.5 \mathrm{~mm}$

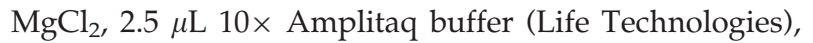
$1.25 \mathrm{U}$ Amplitaq (Life Technologies), $0.25 \mathrm{~mm}$ each dNTP, $0.4 \mu \mathrm{M}$ of each primer, 5\% DMSO and $1 \mu \mathrm{L}$ of DNA extract. Amplifications were accomplished following with a thermocycling program of $15 \mathrm{~min}$ at $95{ }^{\circ} \mathrm{C}$; 55 cycles of $30 \mathrm{~s}$ at $94{ }^{\circ} \mathrm{C}, 45 \mathrm{~s}$ at $58{ }^{\circ} \mathrm{C}, 30 \mathrm{~s}$ at $72{ }^{\circ} \mathrm{C}$; with a final extension at $72{ }^{\circ} \mathrm{C}$ for $7 \mathrm{~min}$. Each water sample was amplified three times to account for stochasticity in amplifications of low quality/quantity DNA (Taberlet et al. 1996; Ficetola et al. 2008). Fragment analysis was conducted on PCR products by dilution in HiDi Formamide mixed with Liz500 size standard then loaded on an ABI3130xl genetic analyzer and visualized using GENEMAPPER 4.0 (Life Technologies).We considered a positive PCR in any one of the three replicates to be a detection. To test sensitivity of our protocol, we performed PCR on serial dilutions of each of the pen test I water samples $(1 \times, 0.1 \times, 0.01 \times, 0.001 \times$ and $0.0001 \times)$ of DNA.

\section{Pen test II: P. bivittatus DNA degradation in water}

To test persistence of $P$. bivittatus DNA in water overtime, we used the same penned snakes at the NWRC Florida field station and followed the protocol as described for pen test I. Initially, we collected and froze water samples in 50-mL autoclaved plastic tubes before snakes were added (time 0), and then, we collected and froze samples after the snakes had been in the water only $15 \mathrm{~min}$ to assess whether we could detect $P$. bivittatus DNA even after a short exposure. After two hours, we removed the snakes and we collected six additional 50-mL water samples from each container. We immediately froze samples from each container representing the 2-h sampling period. We placed the rest of the samples without lids on a table in a roofed outdoor pavilion exposed to ambient temperatures and partial afternoon sunlight. We then removed and froze one bottle of water from each snake at 24, 48, 72, 96 and $168 \mathrm{~h}$. All water samples were shipped frozen to the NWRC Wildlife Genetics Lab in Fort Collins, Colorado for analysis. We extracted DNA following the optimal protocol as described above with the modification of automating a portion of the DNA extraction process. After DNA isolation, initial extraction steps were accomplished following the Forensic Case Work Samples protocol (QIAamp 


\section{A. J. PIAGgiO ET AL.}

DNA Micro Handbook August, 2003) steps 1 and 2 with an incubation at $56{ }^{\circ} \mathrm{C}$ overnight. The extraction process was completed on a Qiacube (QIAGEN) using the Isolation of DNA from the Forensic casework samples Part B program. PCR was conducted as described for our assay design. To accommodate laboratories that have different technological capacities, we evaluated the detection ability of two different DNA visualization methods: fragment analysis on a capillary sequencer and gel electrophoresis (on one PCR replicate of all time points) as described above. For confirmation that positive amplifications were $P$. bivittatus DNA, products from one replicate of one time period (15 $\mathrm{min}$ ) were sequenced.

\section{Field test: application of P. bivittatus diagnostic PCR}

We selected six sites in south Florida to collect water samples for eDNA analysis (Fig. 1). Python bivittatus had been documented at five of the sites and was not known to exist at the final site (http://www.eddmaps. org /florida/species / subject.cfm?sub=20461). We collected ten $50-\mathrm{mL}$ samples (in autoclaved plastic tubes) from each site, along approximately $400 \mathrm{~m}$ transects to increase the probability of detection. Samples were shipped frozen to NWRC where DNA isolations and extractions were conducted within $24 \mathrm{~h}$ of delivery. Samples for each site were pooled by mixing all $50-\mathrm{mL}$ samples in a 1 - $\mathrm{L}$ beaker (total $=500 \mathrm{~mL}$ ) on a magnetic plate with a stir bar and mixed for a minimum of $10 \mathrm{~min}$. Using a $5-\mathrm{mL}$ pipette, we collected a total of three 15-mL subsamples from each site. DNA isolation, extraction, and amplification were conducted from each of the eighteen 15-mL samples following the methods described above (Assay design and pen test II). Products from a single replicate from sites with $100 \%$ positive detection across replicates were sequenced for

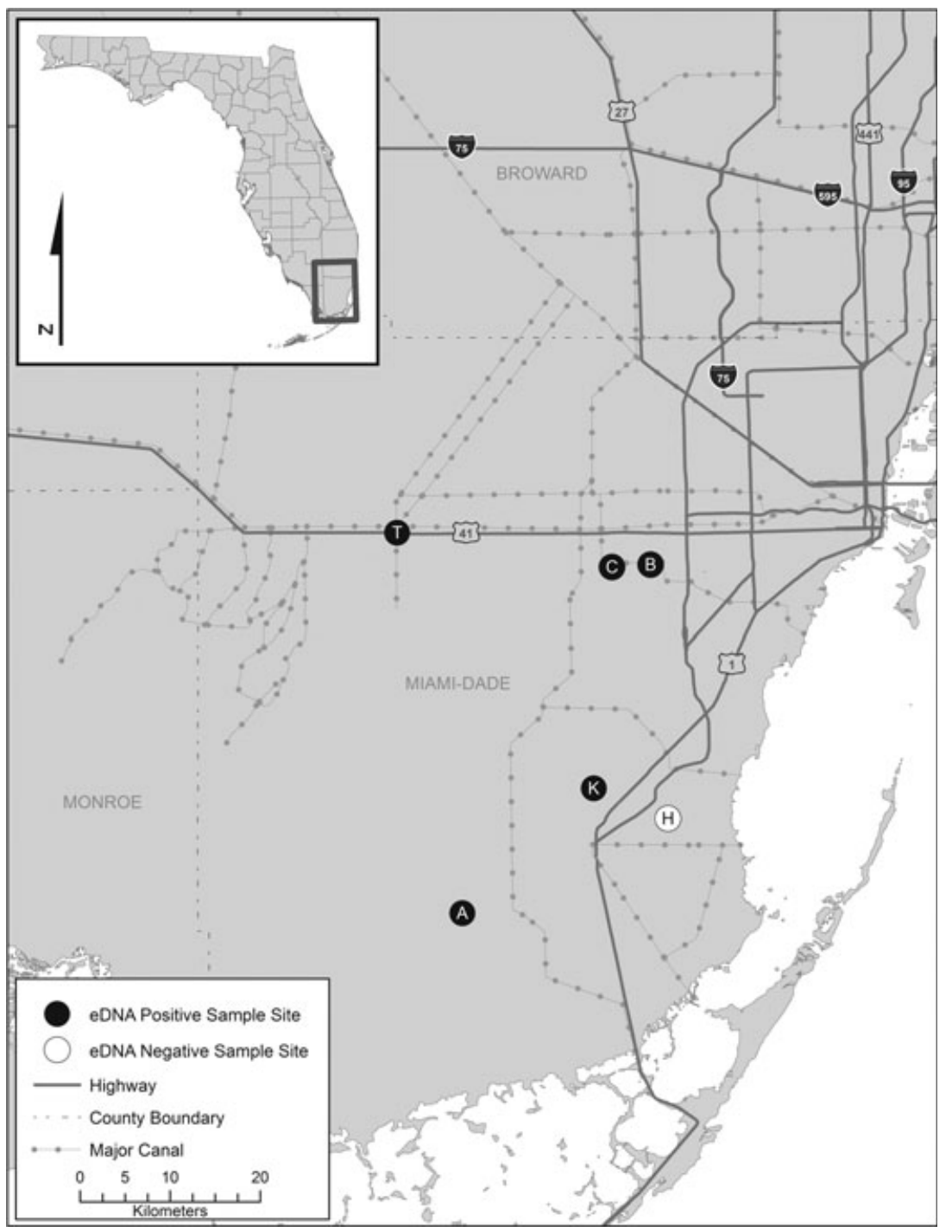

Fig. 1 Map showing sampling areas where water was collected to test for Python bivittatus environmental DNA. All sampling was conducted in Miami-Dade County. Five sites A, B, C, K and T have had documented P. bivittatus and the fourth site $\mathrm{H}$ has not. 
verification that amplifications were of $P$. bivittatus DNA.

\section{Results}

\section{Pen test I}

When successful, we amplified 294-356 bp of Python bivittatus cyt $b$ from the water samples. Amplifications from the QIAamp DNA Micro Kit extractions were highly successful with both isolation methods; however, there was a single failed amplification from a vacuum-filtered isolate (Table 1). The extractions from the PowerWater ${ }^{\circledR}$ Kit were less reliable (Table 1 ); three of the five vacuum-filtered isolates and none of the sodium acetate precipitations amplified. Thus, there were significant differences detected among the four isolation-by-extraction combinations $\left(\chi^{2}=10.41\right.$, d.f. $\left.=3, P=0.0154\right)$, with the differences between the QIAamp DNA Micro Kit and PowerWater ${ }^{\circledR}$ Kit extraction procedures accounting for these differences (Table 1).

\section{Assay design}

Fragment analysis of the species-specific primers resulted in positive detections for all pen test I samples and the positive control with a peak at $99 \mathrm{bp}$. There were no amplifications of Python sebae or $P$. regius DNA. Serial dilutions of the pen test I water samples resulted in consistent detection of $P$. bivittatus DNA at $1 \times(5 / 5)$ and $0.1 \times(5 / 5)$ and showed decline in detection at $0.01 \times(3 /$ 5). However, detections were still possible at $0.001 \times(1 /$ 5) and $0.0001 \times(1 / 5)$. All results from extraction methods tests, subsequent DNA sequencing and dilution series are provided in a spreadsheet in a Dryad Digital Repository http:/ /dx.doi.org/10.5061/dryad.87v3v.

\section{Pen test II}

The PCR primers specific to $P$. bivittatus produced bands for all time trial periods except 0 . Testing of water samples prior to immersion of the snakes verified that the water was not contaminated with Python DNA. Obvious

Table 1 Rates of detection for environmental DNA in water samples exposed to Python bivittatus during pen test I and subjected to two isolation and two extraction methods

\begin{tabular}{llc}
\hline Isolation & Extraction & $\%$ success $(n=5)$ \\
\hline NaAcetate & PowerWater & 0 \\
& QIAamp & 100 \\
Vacuum filter & PowerWater & 40 \\
& QIAamp & 80 \\
\hline
\end{tabular}

degradation began at $48 \mathrm{~h}$ where one sample failed across all three replicates (20\% degradation), which was also true at $72 \mathrm{~h}$. There were no failed detections at $96 \mathrm{~h}$, but at $168 \mathrm{~h}$ three samples failed across all three replicate (60\% degradation; Table 2). There was stochasticity across PCR replicates where at least one replicate failed in five time periods (Table 2). Results from the gel electrophoresis were identical to the fragment analysis. We sequenced one band from the 15-min time period, which produced a $P$. bivittatus DNA sequence. In the Dryad archive, all results from this test are provided in detail in a spreadsheet, along with screenshots of peaks generated by fragment analysis, and a picture of the gel electrophoresis results.

\section{Field test}

There were five sites where we detected P. bivittatus DNA, and all were from sites where the species had been previously sighted (sites A, B, C, K and T; Fig. 1). We did not detect $P$. bivittatus DNA from the site where the species has not been documented (site H). Subsamples and replicates for all five positive sites did not produce consistent results (Table 2). DNA sequences from a single PCR for each site with $100 \%$ detection rate across replicates confirmed that positives were indeed $P$. bivittatus. Data are provided in a spreadsheet, and a DNA sequence (all sequences were identical) as a FASTA file are provided in the Dryad archive.

Table 2 Success in detecting Python bivittatus DNA from water collected in pen test II, which assessed persistence of $P$. bivittatus DNA in water, and from the Field Test. The water samples column shows how many samples collected for a certain time point or locality were positive for $P$. bivittatus DNA. The positive PCR column shows the number of replicates for the samples that were positive and thus represent the stochasticity across runs due to eDNA template quality/quantity

\begin{tabular}{lcc}
\hline Sample & $\begin{array}{l}\text { Water samples positive for } \\
\text { P. bivittatus at least once } \\
\text { (no. of samples) }\end{array}$ & $\begin{array}{l}\text { Positive PCRS (no. of } \\
\text { samples } \times \text { no. of } \\
\text { replicates) }\end{array}$ \\
\hline $0 \mathrm{~min}$ & 0 & 0 \\
$15 \mathrm{~min}$ & $5 / 5$ & $15 / 15$ \\
$2 \mathrm{~h}$ & $5 / 5$ & $14 / 15$ \\
$24 \mathrm{~h}$ & $5 / 5$ & $14 / 15$ \\
$48 \mathrm{~h}$ & $4 / 5$ & $11 / 15$ \\
$72 \mathrm{~h}$ & $4 / 5$ & $10 / 15$ \\
$96 \mathrm{~h}$ & $5 / 5$ & $13 / 15$ \\
$168 \mathrm{~h}$ & $2 / 5$ & $6 / 15$ \\
$\mathrm{~A}$ & $3 / 3$ & $7 / 9$ \\
$\mathrm{~B}$ & $2 / 3$ & $4 / 9$ \\
$\mathrm{C}$ & $1 / 3$ & $1 / 9$ \\
$\mathrm{H}$ & $0 / 3$ & $0 / 9$ \\
$\mathrm{~K}$ & $2 / 3$ & $6 / 9$ \\
$\mathrm{~T}$ & $1 / 3$ & $1 / 9$ \\
\hline
\end{tabular}




\section{Discussion}

We have demonstrated that eDNA from Python bivittatus can be successfully amplified in pen tests and detected from field samples. This method presents a promising new monitoring tool, which could assist assessment of the current distribution of $P$. bivittatus and allow efficient monitoring and documentation of future range expansions. Through testing a combination of methods for isolating and purifying $P$. bivittatus from water, we found that the optimal method was a sodium acetate precipitation along with a QIAamp DNA Micro Kit for DNA purification. Interestingly, this approach isolates DNA from the least amount of water. A possible explanation for this is that during vacuum filtration, we experienced rapid clogging of the filter paper, which may have hindered our ability to gather DNA molecules. Further the vacuum-filtration process may have concentrated inhibitors, which would then interfere with DNA purification. The PowerWater $^{\circledR}$ Kit performed suboptimally and in fact failed to produce any DNA when paired with the sodium acetate isolation method. We could have eluted multiple times from the filter paper to increase our recovery, and perhaps, we did not perform the sodium acetate precipitation properly in the PowerWater ${ }^{\circledR}$ trial. However, the goal was to compare the extraction kits and the QIAamp DNA Micro Kit outperformed the PowerWater ${ }^{\circledR}$ kit in all cases. Although we did not test our primers on the closest relative of $P$. bivittatus, Python molurus (Jacobs et al. 2009), we are not concerned about false positives due to amplification of this species; primarily, because it is not a species that has been documented in the United States except in zoos. The importation of $P$. molurus has been prohibited since the 1970s as it is on the CITIES list (Jacobson et al. 2012). Further, both the forward and reverse primers we designed sit in regions where there are $2 \mathrm{bp}$ differences between P. molurus (NC015812) and $P$. bivittatus (FJ717484). As for the other known invasive pythons in Florida, we are confident, based on our results that the primers presented in this study will not crossamplify in those species.

Understanding the distribution of an invasive species and having an efficient method for detecting range expansions are critical to being able to rapidly deploy control efforts. Eradication efforts of invasive species are expensive and intensive. It is especially challenging to monitor and evaluate success of such efforts by detecting new or missed individuals. In some cases, detection through eDNA will provide a new approach that is more efficient and less expensive than other monitoring methods (Darling \& Mahon 2011). During optimization of the described PCR protocol for the P. bivittatus-specific primers, we observed that the fragment analysis on a capillary sequencer was more sensitive than gel electro- phoresis. However, we were able to develop a PCR cycling regime that produced congruent results through a capillary sequencer or gel electrophoresis allowing for low-cost processing. Our goal was that laboratories with varying capabilities would be accommodated.

Further, this method could be adapted to detect and monitor numerous other invasive reptiles that spend time in or near water sources in Florida, such as the northern African python Python sebae, Nile monitor Varanus niloticus, and spectacled caiman Caiman crocodilus (Reed et al. 2010; Engeman et al. 2011; Meshaka 2011). The ability to detect reptiles with eDNA from water sources also holds promise for the identification and monitoring of species of concern or endangered species. For example, approximately a third of reptile species listed by the U.S. Fish and Wildlife Service as threatened or endangered are sufficiently aquatic such that our results may facilitate development of detection methods (USFWS 2012). Notable candidates might be species of water snakes (Nerodia spp.), map turtles (Graptemys spp.) and crocodilians (USFWS 2012).

PCR amplification of $P$. bivittatus DNA was successful (albeit unreliable) at even the highest dilutions of water (0.0001). The goal of our approach of sampling 10 sites along a transect then pooling and subsampling the pools was to increase detection probability (Thomsen et al. 2012b). Therefore, for studies where testing each sample collected along a transect is preferred, detection probability may decrease. When using small fragments to detect degraded DNA contamination and variability in detection occurs across replicates (Darling \& Mahon 2011). Thus, we found that it was critical to include multiple negative and positive controls and to employ a multiple tubes approach (Taberlet et al. 1996), as is probably true for all eDNA tests. Tests of persistence of $P$. bivittatus eDNA demonstrated that as time since DNA deposition increased beyond 96 hours, detection decreased substantially leading to false negatives (type II error; Darling \& Mahon 2011), although positives found beyond that time frame were true positives. We did not conduct the persistence study long enough to detect the point where complete degradation occurred. However, our finding that by 7 days eDNA had degraded significantly agrees with results from studies conducted in various water systems such as marine (Thomsen et al. 2012b) and freshwater (Dejean et al. 2011). These studies found loss of detectability between 0.9-6.7 and 14 days, respectively. Although results from these studies cannot be directly compared with ours due the differences in aquatic ecosystems and target taxa, it seems that we likely would find complete loss of detectability within 14 days. False positives were never observed in pen or field tests, verifying the specificity of this assay (low type I error; Darling \& Mahon 2011). 
In conclusion, this is the first demonstration that water-borne reptile DNA ( $P$. bivittatus) can be amplified from environmental samples. The method presented here is efficient, inexpensive and does not produce false positives. The availability of this eDNA method is a significant improvement over existing detection and monitoring methods for $P$. bivittatus, which rely on timeconsuming and laborious search and capture of these cryptic and elusive species.

\section{Acknowledgements}

We thank Barbara Freeman for sharing her protocols with us. We are indebted to Michael Milleson for preparing Fig. 1. We also extend our gratitude to three anonymous reviewers whose comments greatly improved this manuscript.

\section{References}

Benson DA, Karsch-Mizrachi I, Clark K, Lipman DJ, Ostell J, Sayers EW (2012) GenBank. Nucleic Acids Research, 40, D48-D53.

Collins TM, Freeman B, Snow S (2008) Final Report Genetic Characterization of Populations of the Nonindigenous Burmese Python in Everglades National Park. Final report for the South Florida Water Management District. Department of Biological Sciences, Florida International University, Miami, Florida, 30p.

Darling JA, Mahon AR (2011) From molecules to management: adopting DNA-based methods for monitoring biological invasions in aquatic environments. Environmental Research, 111, 978-988.

Deagle BE, Eveson JP, Jarman SN (2006) Quantification of damage in DNA recovered from highly degraded samples-a case study on DNA in faeces. Frontiers in Zoology, 3, 11.

Dejean T, Valentini A, Duparc A et al. (2011) Persistence of environmental DNA in freshwater ecosystems. PLoS ONE, 6, e23398.

Dorcas ME, Willson JD, Reed RN et al. (2012) Severe mammal declines coincide with proliferation of invasive Burmese pythons in Everglades National Park. Proceedings of the National Academy of Sciences of the United States of America, 109, 2418-2422.

Engeman R, Jacobson E, Avery ML, Meshaka WE (2011) The aggressive invasion of exotic reptiles in Florida with a focus on prominent species: a review. Current Zoology, 57, 599-612.

Ficetola GF, Miaud C, Pompanon F, Taberlet P (2008) Species detection using environmental DNA from water samples. Biology Letters, 4, 423425.

Foote AD, Thomsen PF, Sveegaard S et al. (2012) Investigating the potential use of environmental DNA (eDNA) for genetic monitoring of marine mammals. PLoS ONE, 8, e41781.

Goldberg CS, Pilliod DS, Arkle RS, Waits LP (2011) Molecular detection of vertebrates in stream water: a demonstration using Rocky Mountain tailed frogs and Idaho giant salamanders. PLoS ONE, 6, e22746.

Greene DU, Potts JM, Duquesnel JG, Snow RW (2007) Geographic distribution: Python molurus bivittatus (Burmese python). Herpetological Review, 38, 355.

Jacobs HJ, Auliya M, Böhme W (2009) Zur taxonomie des dunklen tigerpythons, Python molurus bivittatus Kuhl, 1820, speziell der population von Sulawesi. Sauria, 31, 5-16.

Jacobson E, Barker D, Barker T et al. (2012) Environmental temperatures, physiology, and behavior limit the range expansion of invasive Burmese pythons in the southeastern U.S. Integrative Zoology, 7, 271-285.

Jerde CL, Mahon AR, Chadderton WL, Lodge DM (2011) "Sight-unseen" detection of rare aquatic species using environmental DNA. Conservation Letters, 4, 150-157.
Meshaka WE (2011) A runaway train in the making: the exotic amphibians, reptiles, turtles, and crocodilians of Florida. Monograph 1. Herpetological Conservation and Biology, 6, 1-101.

Meshaka WE, Loftus WF, Steiner T (2000) The herpetofauna of Everglades National Park. Florida Scientist, 63, 84-103.

Pyron RA, Burbrink FT, Guiher TJ (2008) Claims of potential expansion throughout the U.S. by invasive python species are contradicted by ecological niche models. PLoS ONE, 3, e2931.

Rawlings LH, Rabosky DL, Donnellan SC, Hutchinson MN (2008) Python phylogenetics: inference from morphology and mitochondrial DNA. Biological Journal of the Linnean Society, 93, 603-619.

Reed RN, Krysko KL, Snow RW, Rodda GH (2010) Is the northern African python (Python sebae) established in southern Florida? IRCF Reptiles and Amphibians, 17, 52-54.

Rodda GH, Jarnevich CS, Reed RN (2009) What parts of the US mainland are climatically suitable for invasive alien pythons spreading from Everglades National Park? Biological Invasions, 11, 241-252.

Smith HT, Sementelli A, Meshaka WE, Engeman RM (2007) Reptilian pathogens of the Florida Everglades: the associated costs of Burmese pythons. Endangered Species Update, 24, 63-71.

Snow RW, Brien ML, Cherkiss MS, Wilkins L, Mazzotti FJ (2007a) Dietary habits of the Burmese python, Python molurus bivittatus, in Everglades National Park, FL. Herpetological Bulletin, 101, 5-7.

Snow RW, Krysko KL, Enge KM, Oberhofer L, Walker-Bradley A, Wilkins L (2007b) Introduced populations of Boa constrictor (Boidae) and Python molurus bivittatus (Pythonidae) in southern Florida. In: The Biology of Boas and Pythons (eds Henderson RW and Powell R), pp. 416438. Eagle Mountain Publishing, Eagle Mountain, Utah.

Taberlet P, Griffin S, Goosens B et al. (1996) Reliable genotyping of samples with very low DNA quantities using PCR. Nucleic Acids Research, 24, 3189-3194.

Thomsen PF, Kielgast J, Iversen LL et al. (2012a) Monitoring endangered freshwater biodiversity using environmental DNA. Molecular Ecology, 21, 2565-2573.

Thomsen PF, Kielgast J, Iversen LL, Møller PR, Rasmussen M, Willerslev E (2012b) Detection of a diverse marine fish fauna using environmental DNA from seawater samples. PLoS ONE, 7, e41732.

U.S. Fish and Wildlife Service (2012) Web list of threatened and endangered reptiles in the USA. Available from http://ecos.fws.gov/ tess_public/SpeciesReport.do?groups $=$ C\&listingType $=$ L\&mapstatus $=1$ (accessed 13 August 2012).

Valiere N, Taberlet P (2000) Urine collected in the field as a source of DNA for species and individual identification. Molecular Ecology, 9, 2150-2152.

Wong K-L, Wang J, But PP-H, Shaw P-C (2004) Application of cytochrome b DNA sequences for the authentication of endangered snake species. Forensic Science International, 139, 49-55.

A.J.P., R.M.E. and M.L.A. participated in study design. A.J.P. and M.W.H. conducted laboratory work. A.J.P., M.W.H. and R.M.E. performed data analysis. J.S.H., K.L.K. and W.E.B. cared for captive animal test subjects and performed field trials. A.J.P. wrote the manuscript with help from R.M.E., M.L.A. and M.W.H. All authors read and approved the final manuscript.

\section{Data accessibility}

All relevant data and DNA sequence: Dryad submission URL is http://dx.doi.org/10.5061/dryad.87v3v. 